\title{
TERF2 Gene
}

National Cancer Institute

\section{Source}

National Cancer Institute. TERF2 Gene. NCI Thesaurus. Code C20562.

This gene is involved in the negative regulation of telomerase activity. 